\title{
NEW PRODUCT LAUNCH SUCCESS: A LITERATURE REVIEW
}

\author{
Alexander Salmen ${ }^{1,2}$ \\ ${ }^{1}$ Mendel University in Brno, Zemědělská 1, 61300 Brno, Czech Republic \\ ${ }^{2}$ Meierfrankenfeldstr. 37, 58710 Menden, Germany \\ Link to this article: https://doi.org/10.11118/actaun.2021.008 \\ Received: 13. 2. 2020, Accepted: 30. 12. 2020 \\ To cite this article: SALMEN ALEXANDER. 2021. New Product Launch Success: A Literature Review. Acta \\ Universitatis Agriculturae et Silviculturae Mendelianae Brunensis, 69(1): 151-176.
}

\begin{abstract}
This review article deals with the current state of knowledge on the topic of launching new products on the market and the success factors that constitute launch success. As things stand today, it can be stated that the existing research work already covers a broad range of topics and that there is an extended pool of relevant results, which, however, appear rather confusing for the most part due to the lack of comparability of methods and indicators and a large number of specific topics dealt with. It also reveals many gaps of science for future research. The method of this article uses integrative review approach with elements of semi-structured methods to analyse the content of studies concerning the research topic and is thus providing an up-to-date overview of the object of research, which reflects the state-of-the-art on questions relevant to practice and science. Therefore, databases like Google scholar and the university catalogues of the university in Dortmund and Cologne have been used, focussing only on sources that were also listed in Scopus and the Web of Science. The current change through megatrends like the digitalization is also taken into account. Literature on this topic is evaluated to determine the influence of current and future megatrends on the optimal design of product launches. The result is that on the one hand there is already a secure pool of success factors, best-practice methods, typologies and investigation of phenomena encompassing the product launch. On the other hand, the introduction of products to the market is a complex process whose orientation towards the maximum prospects of success must be individually aligned to the respective specifics of the market, product, business model and target group (internal and external), so that there can be no general recipe for success, which applies to every situation. The new opportunities provided by digitisation will also play a key role in this respect.
\end{abstract}

Keywords: product launch, launch success factors, digitalization, new product performance

\section{INTRODUCTION}

The object of the article is to provide a compact summary of current scientific knowledge on the topic of launching new products on the market, regarding current trends, environmental changes and possible fields for future research. Therefore, the literature has been analyzed using content analysis via an integrative review methodology as described in Snyder (2019) to show which fields of product launch have been analyzed, which are the resulting findings, how relevant they are for practitioners, which methods have been used and which scientific gaps still exist today.

The subject of research concerning the launch of new products is of the greatest interest to business in general and to the success of businesses as a whole, as numerous studies show the link between innovation and profitability (Cho and Pucik, 2005; Langerak and Hultink, 2005; Shepherd and Ahmed, 2000). The launch process is the final phase of the innovation process (Trommsdorff and Steinhoff, 2013). Product launch is the process 
that is most critical to the success of the innovation process because it is the process in which most costs are incurred during the innovation process (Cooper and Kleinschmidt, 1988; O'Dwyer and Ledwith, 2008). In this respect, it is of vital importance with regard to the prospects of success and risks of an innovation project. Nevertheless, only $4 \%$ of the literature on new product development still deals with the question of product launch (Kou and Lee, 2015). The current situation is a drastic change, triggered by the fourth industrial revolution, which also has a lasting impact on the aspects surrounding the product launch of new products (Brynjolfsson and McAfee, 2014; Simon, 2012). The changes that are to be expected for the product launch are therefore also taken into account here with regard to existing studies and literature.

Nowadays, the focus of recently-published studies of the subject "new product launch" treat the following questions. First, complex models have been developed, using assumptions that are based on previous findings on how to obtain launch success. These models try to depicture the complex interrelations between identified factors that might explain why companies fail or achieve in introducing new products into the market, and have been tested empirically. A second stream inspects phenomena around the product launch from a focussed perspective. A third stream tries to make decisions around the product launch operation for management and thus develops models in order to conceptualize aspects around the launch process.

Articles concerning the subject of introducing new products to the market, use the term "launch", and in very few exceptions, "entry" (Green, Barclay and Ryans, 1995; Jiang, Qu and Jain, 2018) to describe the introduction of a novel product to the market. The article focuses on all types of products, services and markets, in order to get an overall and comparing view. Overall, since 200534 papers have been core of analysis in this paper and are displayed in table one. Moreover, some 20 additional papers have been used to proof the found results. These papers contain knowledge about 30 years of knowledge and research on product launch, based on older studies already.

The author of this paper considers the following structure to be beneficial when dealing with the topic. First, the question of the definition of the central terms on the subject of "new product launch" will be examined (Section 2). Subsequently, Section 3 provides a critical treatment and discussion of subjects that have been target of scientific research, and delivers an overview about the current status quo of science. The current literature will be systematised according to used methods, used construct definitions and contradictions with other research results. It does not matter whether phenomena in the area of success factors are focused or considered individually, but all those factors are considered which either demonstrably have a relevant influence on success, or at least have enjoyed great attention in research. Further phenomena, as well as a comparison of different typologies of different clusters of market launches, which have been dealt with in the research on market launches, are subsequently considered. The section also contains an overview of investigation of future trends. The author considers the question of how the product launch of the future will change due to current economic trends to be relevant. The article ends with a discussion (Section 4), followed by a conclusion in Section 5 .

\section{TERMS DESCRIPTION AND METHODOLOGY}

\section{Terms Description}

In order to be able to research an object of research publicly, a minimum common understanding of terms is required, which is shared by all researchers. In the discussion about the launch of new products, difficulties arise from the very beginning with regard to essential definitions of the topic "new product". (Trommsdorff and Steinhoff, 2013; Hauschildt et al., 2016). Radical innovations are rare, such as the steam engine. However, all known approaches to the definition of innovation contain the idea that something "new" has to emerge: "new process/ introduction to the market" (Brockhoff, 2010); "relevant novelties for the first time" (Trommsdorff and Schneider, 1990). The "product" as such also gives rise to definition problems. In the traditional understanding, products are material goods. Since the 1970s, the concept of a product has been increasingly extended to include material and complex offers. The term "innovation" therefore refers analogously to an ever larger circle (Trommsdorff and Steinhoff, 2013). In this case, the product consists of a complex offer. In the literature, this has been taken into account to some extent when, for example, the product launch processes in the software industry have been examined (e.g. Green, Barclay and Ryans, 1995; Ittner and Larcker, 1997), or service like maintenance contracts for machines are subsumed under the category "product” (Döllgen, 2018).

For the introduction of a new product into the market, most frequently the term "launch" is used, or sometimes the word "entry". Homburg (2017) as well as most authors consider the new product launch as the last step of the innovation process. In this respect, the product launch is to be seen on a time and process axis in relation to the innovation process at the end, and in relation to the product life cycle at the beginning, although some authors extend the product life cycle also to the development phase (e.g. Enis, Lagarce and Prell, 1977). It is undisputed that the product launch is a process that can be attributed to marketing. An assignment at the 
end of the innovation process, in which marketing activities only play an accompanying role, therefore speaks for an operational manageability of the terminology. Kuhn (2007) defines this as "the phase from the beginning of the acquisition activities to the beginning of the declining growth of the new product on the market (...)". It comprises all external and internal acquisition measures aimed at supporting the development of the new product in the market. The aim of the new product launch is to bring about the success of the new product on the market.

Success measurement is also an enormous issue, related also to definition and measurement methods. These can only be used in a meaningful and comparable way if they are able to relate the contribution of measures to the achievement of a specific objective. What is the goal of a product launch? When is this successful? Using only one indicator would "probably be an oversimplification for most firms" according to Di Benedetto and Calantone (2007). They, for instance, use a sevenitem scale of performance which was adapted from the project Newprod studies of Cooper and Kleinschmidt (1987, 1993). Lee et al. (2011), for instance, define new product performance as financial performance (market share, Profitability) and strategic performance (customer satisfaction and market extension).

In general, it has therefore become common practice to regard launcher success as a weighted average of various indicators (Kuhn, 2007). More recent studies refer to the success term as "new product performance". Most of the reviewed studies use weighted indicators based on multiitem scales to define success, containing financial success (e.g. product or company profitability - (e.g. Cooper, Edgett and Kleinschmidt, 2004), market success (e.g. product perception, market share, sales numbers) and figures that relate the real numbers to forecasted numbers (e.g. speed, sales estimations - e.g. Kuhn, 2007).

Most of the studies distinguish also based on a differentiation between strategic decisions/ variables and tactical decisions/variables, where the definition in most of the studies is used similar. As can be seen well in Song, Song and di Benedetto (2011), strategic decisions concern general issues about product, market, and competition strategy (such as "target groups, product positioning, timing or order of product entry, and alliances and mergers" (Fraenkel, Haftor and Pashkevich, 2016)), and are taken in an early stage of product development. Tactical decisions concern the elements product, pricing, promotion, distribution and supply chain execution and are taken when the product is completed. Normally, tactical launch decisions are defined according to the "traditional elements of the marketing mix and thus encompass product, pricing, promotion, and distribution decisions” (Talke and Hultink, 2010).

\section{Methodology}

This article is an integrative review article with aspects of semi-systematic review methods (Snyder, 2019). The literature that concerns the topic shall be collected, analysed and compared. The subject of new product launch revealed to be a wide topic which integrates many different problem categories, research methods, variables and objectives. Therefore, a strictly systematic review revealed to be inadequate. Instead, an integrative research approach has been used to analyze different sources, and present an overview of used methods, researched topics and results. A further objective of the article is to find evidence of the effect of some researched factors, elements of systematic review approach has been used: Articles have been compared concerning the definition of constructs, number of respondents, target markets and outcomes in order to find effects and results that are confirmed by several studies. The subject shall be structured according to importance, relevance and themes of the findings. The situation which is treated in this article, is when the company has no sales experience concerning a new product which could be used to draw conclusions for an entry strategy.

The review methodology is effectuated in five steps:

1. selection of fitting key words;

2. research on scientific databases;

3. selection of articles;

4. select additional articles from the selected sources in point (3);

5. development of key categories and analysis framework;

6. comparison and discussion.

The key words (1) had to be defined by a first pre-analysis of the literature. Several key words have been tested to find relevant literature. Also, key words used by relevant articles have been used to find additional relevant articles. After defining the subsequently cited key words (1), research has been made in 2 ways: databases like google scholar and the University catalogues in Dortmund and Cologne have been scanned $(1+2)$ using suitable keywords like "product launch", "new product launch", "product launch process", "product launch international,"entry" and "launch success factors". Target was to find literature which reveals information about success factors of the launch phases, not about previous steps of the innovation process. The results of the research in scientific databases contained some 10.000 articles of which the most part was not suitable for the purpose of this work, as it treats topics of earlier innovation phases (e.g. Khajavi et al., 2015), influences that have an impact on the design of the launch process but not centrally about success factors themselves, (e.g. Bruce, Daly and Kahn, 2007), evaluation tools for choosing the right launch strategy (e.g. Chen, Shen and Chiu, 2007), or entering new markets with 
existing products (e.g. Bhalla, 2013). Furthermore, many articles that have been displayed in the search result list, treat the subject of „launch" not as their major topic, but only as a marginalia and have thus not been analyzed further. Only journals that fulfil scientific demands and are listed on Scopus have been chosen. According to these criteria, studies analyzed in this article have been manually chosen (3) if they treat the detection of links between launch design elements, launch influences, and the launch success. Also, a focus has been laid on the relevance for a broader and international audience. Hints for this criteria have been, for example, the study size, the number of citations of the study in other suitable articles, the use of suitable models to create a fitting image of complex links (e.g structural equation modelling) and the generalizability of results or the general relevance of the topic as subjective criteria. Also, most of the studies which just treat the subject of launch without enabling to gain knowledge about launch-success-critical topics, have been put aside. Also those studies that treat the entry of new markets with existing products, have been excluded. In a second step, keywords of studies that treat the most important topics, have been used for a second analysis based on these keywords, and second, research on articles that cite these studies and fit to their topics. After thus identifying the main articles, the literature in those articles has also been analysed (4) in order to identify further sources which could be source of interest for this article as well.

The literature of the last 15 years has been reviewed. This time period is a little longer than comparable studies (Gorman, Hanlon and King, 1997; Tracey, 2014; Bocconcelli et al., 2018), but the scope of this article is more narrow and justifies a wider time period. Tab. I shows the main studies after the year 2005 on which this article is based and displays a resume of contents and analysis. Moreover, this work is based on additional literature which provides supplementary contributions but not majorly, and which has been used to validate the found results. It is not listed in the Tab. I.

Even though the literature available in the early years until the year 2000 uses different definition of terms and measuring methods and has thus been certified inter alia for this reason to suffer from a lack of scientific foundation (Ernst, 2002; Hauck et al., 2016), the scientific inspections effected on the topic have already provided a large body of knowledge concerning success factors of the product launch, best practices, launch types and clusters, and differences between diverse product categories and markets.

In order to develop key categories for an analytical framework (5), the contents of the studies have been analysed to find clusters of themes which were treated by several studies. As a consequence, this structure allows to conclude which topics that have been treated in the reviewed articles have apparently the highest significance and create product launch success. For this work, these clusters have been proved to be product advantage and innovativeness, management, pricing, market orientation marketing and market research, international context, launch timing, cooperation within the supply chain, resources, market attractiveness, Different product categories. All factors which have been treated in the chosen literature but do not fit to these clusters, but have been relevant nevertheless in the eyes of the author, have been displayed under "other phenomena". Within the analyse (6), articles have been compared to reach the goals of the article: present which fields of product launch have been analysed, show the resulting findings, find effects that several studies could confirm and compare their trustworthiness, show their importance for researchers and practitioners, and reveal which methods have been used and which scientific gaps still exist today.

\section{FINDINGS AND TREATMENT OF IMPORTANT LITERATURE IN THE LAST 15 YEARS}

In the last 15 years since 2005, research has treated several subjects. First, the findings concerning success factors of the product launch have been widened, deepened and validated. Second, special questions and different phenomena around the product launch have been treated. A third topic is the best-practice and typology question that has been inspected. All these three topics have been treated empirically, basing on surveys or case studies. A fourth topic concerns the optimization of daily decisions around the new product launch. These questions have been treated by authors via the development of theoretical models.

The question of success factors appeared very early in science. Thus, a wide range of suspected success factors have been discussed very early in history. Kuhn (2007) published an extensive work based on an analysis of earlier literature and earlier surveys, and of 178 B2B and B2C companies in various sectors in Germany and Austria. The work also contains typologies of launch, and different clusters. She provided a regression analysis and a cluster analysis to achieve that target. The work could mainly confirm lots of these findings. Later, other studies with a similar sample size followed.

\section{Product Advantages and Innovativeness}

The product proprieties have soon be suspected to be one of the most relevant factors for new product performance. Many ancient studies proved the relevance of product proprieties to yield new product launch successfully. Kuhn (2007) can show in her survey that indeed the product related perceived product advantages, as well as 


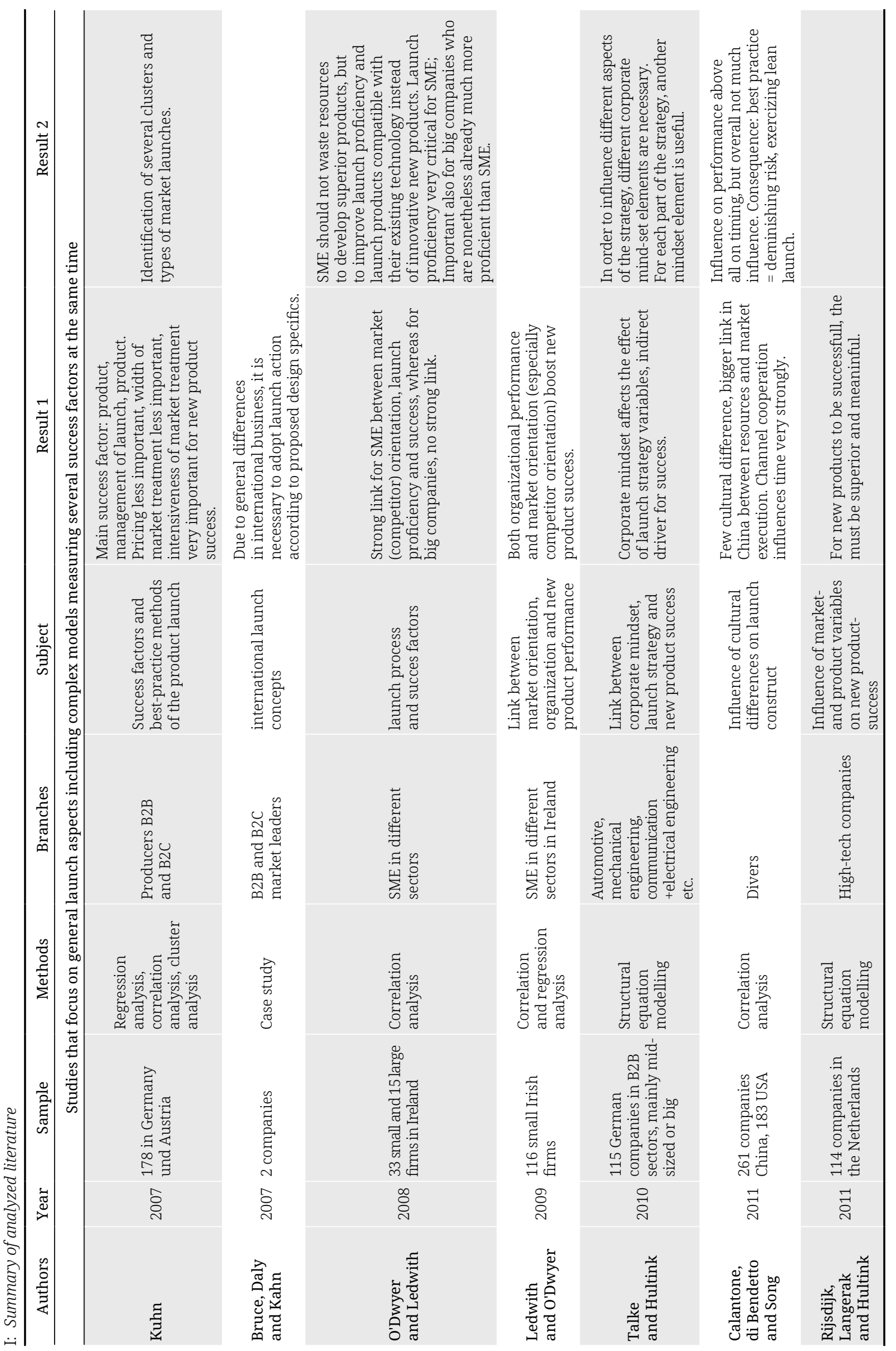




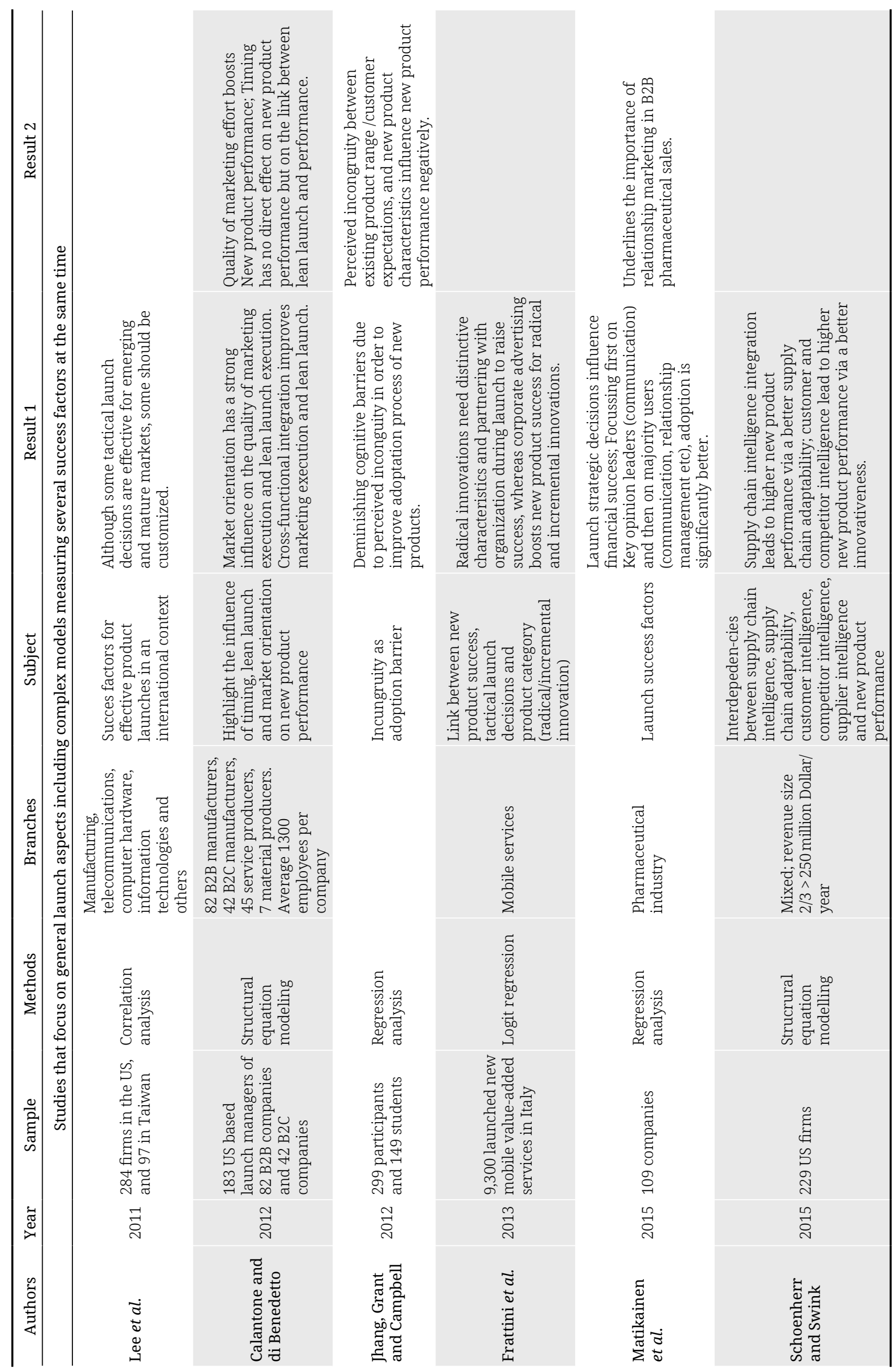




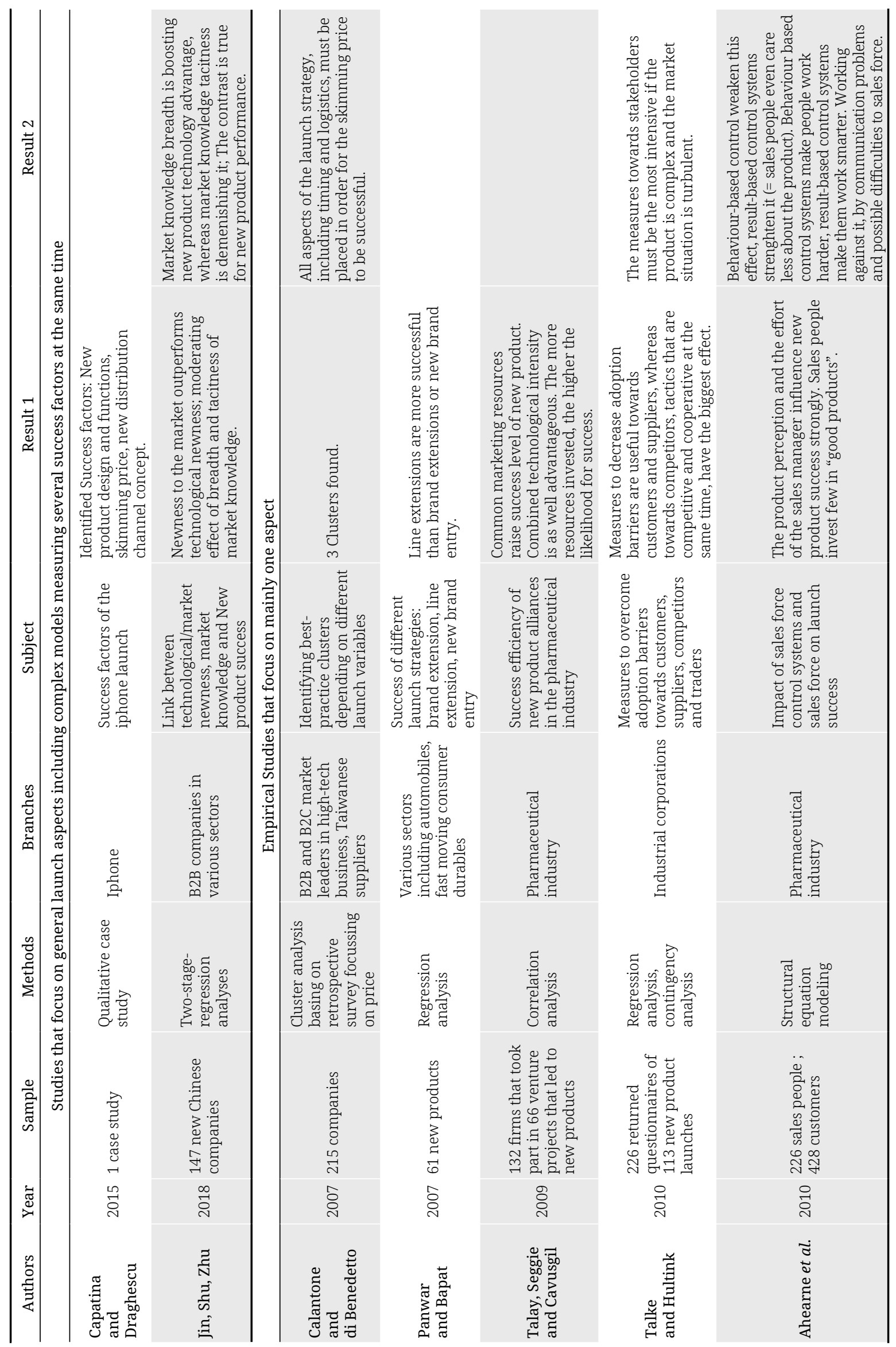




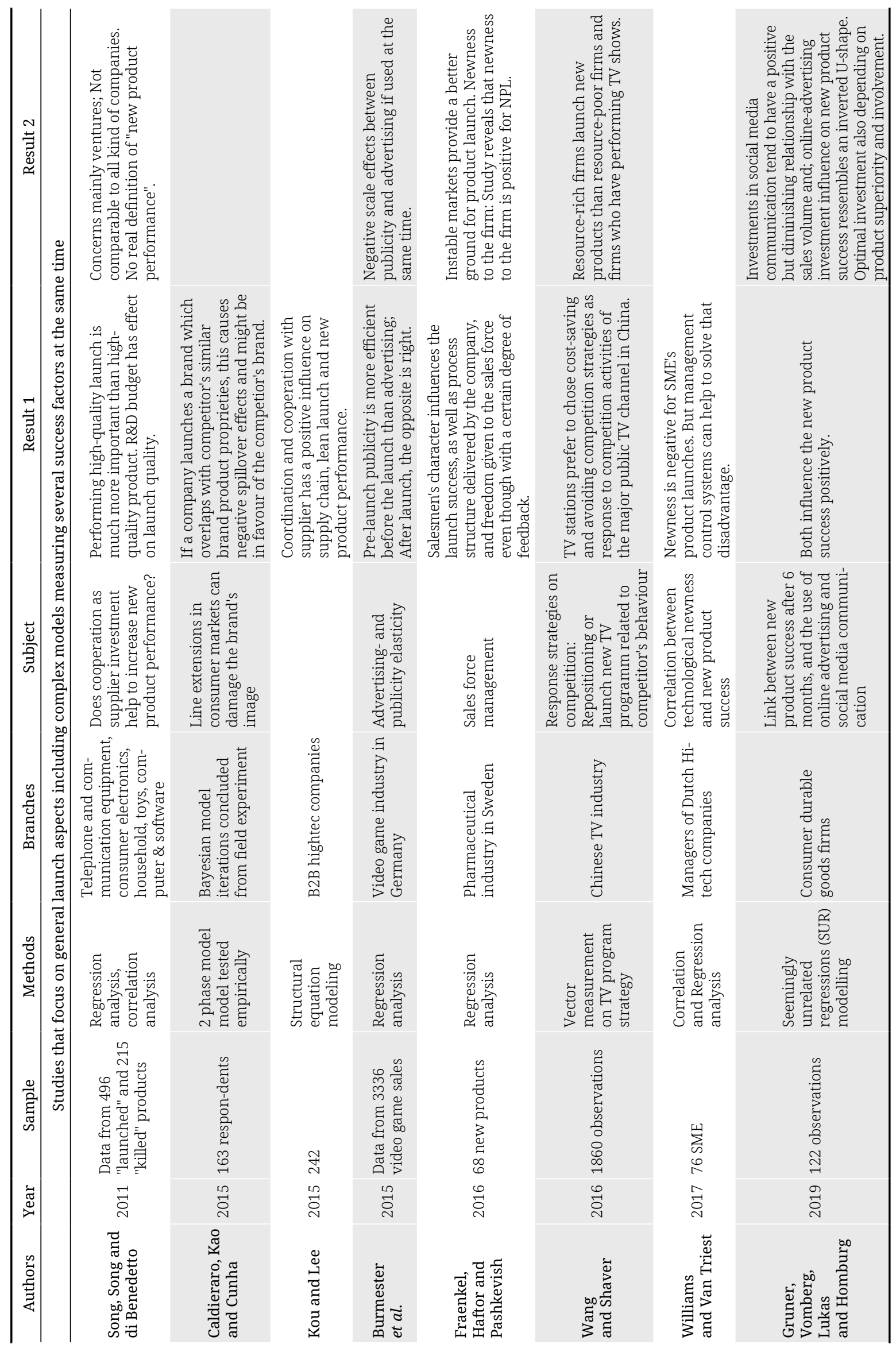




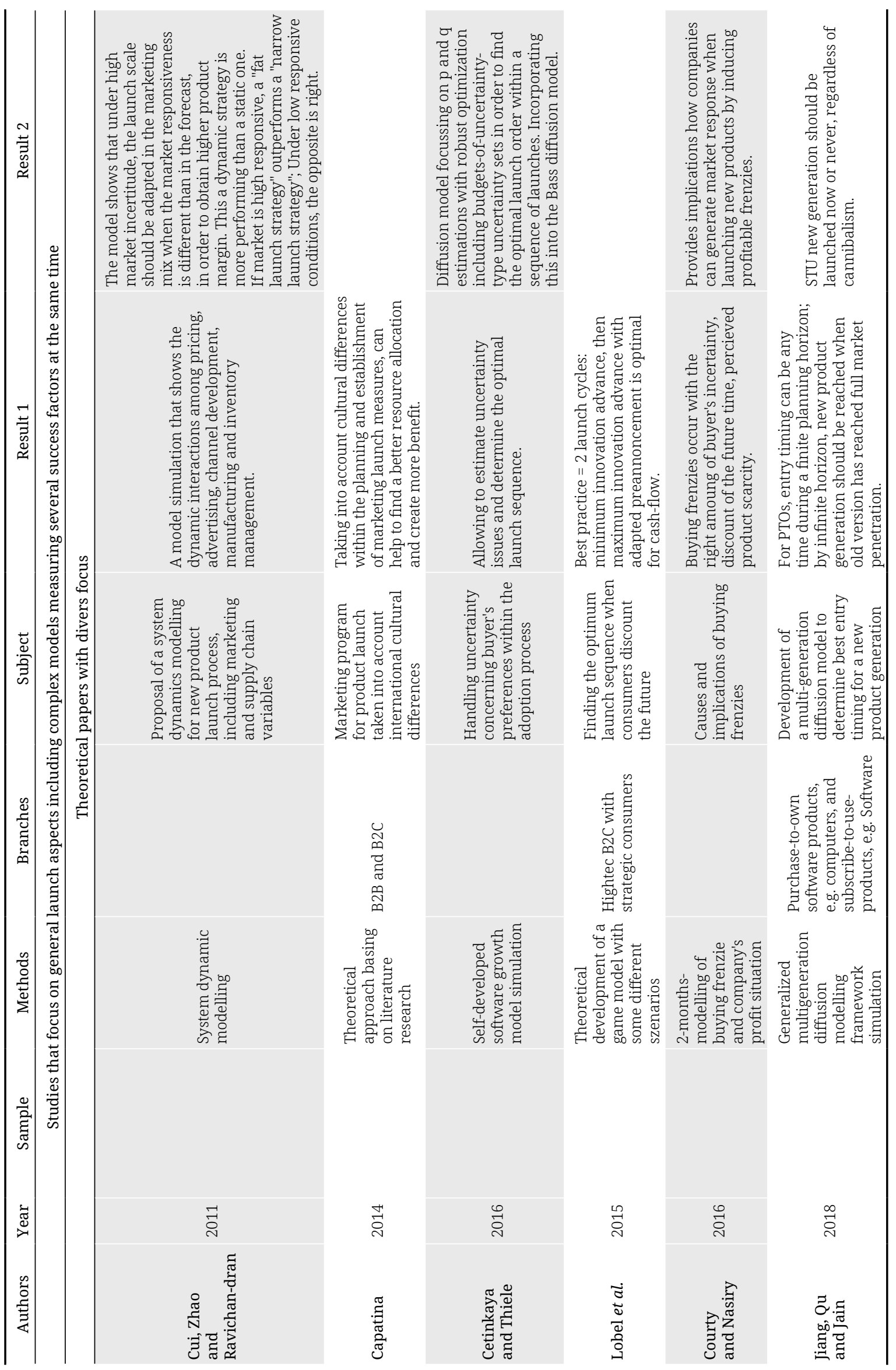


the perceived cognitive risks or complexities of the product, have a significant influence on launch success. Another study (O'Dwyer and Ledwith, 2008), examined with 33 small and 15 big firms in Ireland, yet could not find a link between product superiority and product launch success. The authors admit that in order to establish relevant results, a larger sample would be necessary. Also they conclude that the necessary investment to develop a superior product and to provide the necessary proficiency for a successful launch cannot be supposed especially in small firms. Thus, even though started with a good product, especially small firms have problems to take profit from it because necessary investment in the pre-launch phase eats the benefits. The yet more complex link between product superiority and new product success is also treated by a study of 141 hightech companies in the Netherlands which finds that in order to be successfully launched, a new product must be superior (outperforming competitors) AND meaningful (bring significant benefits to potential customers) (Rijsdijk, Langerak and Hultink, 2011). The question of advantageous product proprieties leads to the characteristic of product innovativeness. The question if product innovativeness (if the product is new to the company or to the market) leads to higher new product performance has also been research topic in some studies, but not as "the only" topic. Kuhn (2007) finds that the newness to the market has a positive influence on the new product performance. Song et al. (2011) find that the newness to the market is only advantageous if the market potential is big, and that for all market sizes, the effect of launch execution is higher than the effect of product innovativeness. O'Dwyer and Ledwith (2008) and also others (e.g. Williams and Van Triest, 2017) find that innovativeness (new for the company) is rather disadvantageous, especially for SME (because it requires huge resources to develop a really innovative product) than advantageous - a link that also a study of 147 new ventures in China (Jin, Shu and Zhou, 2019) and another study (Ozer and Tang, 2019) can confirm, because they find that the product propriety "new to the market" affects the new product performance more positively than the attribute "new product technology".

Lee et al. (2011), supporting this thesis, show a possible explanation for that phenomenon: It is "product innovativeness to the customer that affects new product performance rather than product innovativeness to the firm". The study of O'Dwyer and Ledwith (2008) also confirms that if a product requires new technology inside of the company and is thus not based on existing strengths and technologies within the company, the effect on the company's success is negative especially in SME. Companies should thus focus more on products that are not extremely new but match with their existing strengths and technologies. Lee et al. (2011) conclude also that "it is possible for firms to shape consumers' perceptions of an innovative product in a favourable position" instead of launching a radically innovative product. The importance of such "story telling" strategy is also well documented in a case study about launch tactics of high-tech companies (Simakova, 2010). A second explanation for the different launch success level of radical towards incremental innovations can also be found in the different requirements for tactical launch measures such as advertising, communication and cooperation measures within the sales channel (Frattini, Dell'Era and Rangone, 2013). Whereas radical innovations need the be supported by communication of distinctive product characteristics and partnering with organizations during the launch in order to reduce perceived product risks, corporate advertising can boost new product sales for both incremental and radical innovations by causing awareness for the new product (Frattini, Dell'Era and Rangone, 2013). The conclusion from the opening question could as a consequence be answered as follows, on the basis on the current results. It is shown that innovativeness as such, does not necessarily create success but it requires higher resources to create an innovative product and to launch it. To be convinced of a new product, the buyer must be aware that the product is better, and the cognitive costs of the new product need to be reduced therefore (Kuhn, 2007). Even if the product is better, if the advantages are not communicated to potential buyers, they will not buy the product because they are not aware of the product advantage. Also, if the launch is exercised with poor supply chain performance, it can happen that even though there is demand, products cannot be sold because they are out of stock. In this case, even innovative and advantageous products can fail. The measures of bringing the product advantageous close to potential buyers are subsumed in a construct called "launch execution" (Calantone, Di Benedetto and Song, 2011) or "launch quality" (Song, Song and di Benedetto, 2011). A better product itself helps to obtain a better launch performance, but only with other measures installed, it will create success. These measures can be found in the launch execution and management of the launch (see next points). Above all, the communication measures towards potential customers are required ingredient to allow product advantageous to enfold their full power. This presumption is in congruity with a study from Matikainen et al. (2015) who find in a study comprising 109 pharmaceutical companies in Finland and abroad, that customer acceptance of a product is fostered by measures that target on convincing opinion leaders from the product advantage during the early stage of the launch phase. The result underlines the importance of the product proprieties and the perceived product advantage for the ongoing of the adoption process. 


\section{Management}

The launch process within an organization has also been a topic of survey as a success driver. However, every study has an own definition of what management comprises in the context of launch. Kuhn (2007) defines for her study indicators like "top-management-support", "market orientation", "intensity of schoolings", "cooperation inside of the company", "planning", and "resource equipment". O'Dwyer and Ledwith (2008) use the term "proficiency" to describe similar characteristics such as executing "market testing, launch budgeting, launch strategy, and launch tactics". However, both studies confirm a significant link between management variables and launch success, as also supposed in earlier studies. Kuhn (2007) finds a link between the motivation of the management, the extent of internal cooperation and market orientation and product success. O'Dwyer and Ledwith (2008) also confirm the link between proficiency and new product success confirmed also by another study (Millson, 2012). It seems to be logical that if company management is motivated and cooperation in the company is high, the level of proficiency is higher. Similar definitions are used in a study of Calantone, di Benedetto and Song (2011), examined with 261 companies in China and 183 in the US. Calantone, di Benedetto and Song (2011) use the following constructs to describe management constructs: execution of marketing activities, business unit resources, cross functional integration and launch timing (understood as having the right amount of product at the right place at the right time). Also this study was able to confirm the link between management and launch success, with the strongest correlation on the launch timing and the weakest in the cross-functional integration. The result of this study is also a strong support for the impact of managerial input as it consists of a comparison sample of companies from different cultures. The importance of the management aspect is also underlined by a study of Song, Song and di Benedetto (2011) who inspect 711 first launch projects undertaken by new ventures. They find that the right pricing strategy, develop high quality promotional programs, efficient market research and effect on-time delivery (called "timing" in Calantone, di Benedetto and Song (2011)) is more important than an innovative product. One can conclude that the management aspect and the product aspect belong together: If a product is perceived to be innovative and good, it motivates the management team to effect a good launch. Other studies underline this link between management motivation and launch success (Talke and Hultink, 2010; Kuester, Homburg and Hess, 2012).

\section{Pricing}

Earlier studies have examined the effect of price setting on the success of product launch. Therefore, so-called "skimming price" which aims at achieving high margins due to high prices linked to product superiority, was compared to "penetration price" strategy which intends to get high market share by low-price setting (Hultink et al., 1997). As a tactical launch variable, the setting of the right price might be determining success/failure, if customers perceive the price too high and refuse purchase. On the other hand, a high rebate in the beginning could render customers suspicious as well (Lee et al., 2011). Apart from the later treated international component of price which leads to the implication that price should be handled different in various markets, the general aspect of the price functioning during launch phase has been examined in recent studies as well. Calantone and Di Benedetto (2007) conduct an analysis of 215 leading B2B and B2C companies concerning their price strategies and can identify clusters that show the consequences of price decisions combined with other launch variables. The study shows that "neither skimming nor penetration pricing necessarily leads to superior performance”. According to them, success or failure depends on the coordination with the rest of the launch strategy. If a skimming price shall be successful, it is necessary to find out the market needs in order to use the right arguments to convince customers. Moreover, information and coordination for the right timing is needed. The logistic aspect must not be neglected: Channel partners need enough stock and information about the product to meet demand. If the penetration price strategy is selected, it can lead to a fast development of market share if logistic and production capacities are well configured. That's why the penetration strategy requires excellent preparation in production forecasting and sales team preparation. The complex links between performance, customer perceiption and price strategy is also confirmed by other studies (Ingenbleek, Frambach and Verhallen, 2013). In the case of the i-phone launch, the case study of Capatina and Draghescu (2015) find hints that one of the success factors of the i-phone launch was the use of a price skimming strategy.

The work of Kuhn (2007) also ponders the question which price strategy is superior. The work could not find any correlation between new product success and the chosen price strategy "skimming price", "penetration price” or "medium price level". However, her analysis was conducted only on the surface concerning price, whereas the study of Calantone and Di Benedetto (2007) analyzes price structures before the background of other variables that enlighten ways to optimize price tactics.

Leaving the more general view on skimming or penetration prices apart, a more detailed question concerns buying frenzies. An example is the launch of the i-phone, when consumers build long queues in front of the Apple shops just to be the first among new i-phone consumers. Courty and Nasiry (2016) 
conducted theoretical research about the question, what leads to buying frenzies and what implications these frenzies have on managerial decisions. With a theoretical model, they could show that frenzies occur when customers fear scarcity and discount the future time, yet not too much. Also, the right amount of customer uncertainty is needed. Then the model shows that frenzy strategies can create high bargain effects for the company (Courty and Nasiry, 2016). Scarcity and uncertainty can be established by the fitting preannouncement strategy. As a result, company's promotion and production strategy needs to be well coordinated when trying to prepare buying frenzy strategy. Overall, it gets clear that the right choice whether to take skimming price, penetration price or other price strategies, depends on several situational factors.

\section{Market Orientation, Marketing and Market Research}

Market orientation has been identified by earlier studies and later discussed by recent authors as an important driver of launch success. It has been defined as "organization-wide generation and dissemination of market information on customer needs and wants, and organizational response to this information" (Jaworski and Kohli, 1993; Calantone and Di Benedetto, 2007). Market orientation is a factor that is more or less defined in a similar way in the studies that treat the subject. Most of the recent studies subsume also market research and marketing under the term "market orientation". Kuhn (2007) finds on that basis that the market orientation has a positive influence on the internal adaptation (the acceptance of the management to promote the new product), and on the success of the product launch. Another study (Kim, Shin and Min, 2016) comes to the conclusion that market research and marketing skills lead to cost or product advantages that later lead to higher new product performance, widened by Calantone and Di Benedetto (2007) who state that knowing the market necessities, supports, and is the requirement, for choosing the right pricing strategy and thus contributes significantly to outperforming competitors and achieve better financial benefits. Calantone, di Benedetto and Song (2011) deliver an amendment to the definition of market orientation by clarifying how it can be exercised: "frequent meetings with customers, interdepartmental meetings to discuss competitive strategies or market trends, periodic checking of product development to keep it in line with customer needs, taking corrective action when customers are unhappy with service quality, and so on.” Their work shows a strong link between market orientation, market research and the execution of launch activities. Another study that highlights the aspect of market orientation is O'Dwyer and Ledwith (2008). They inspect the link between market orientation (understood as customer orientation, competitor orientation and interfunctional coordination), organizational performance and new product performance. For small firms, they found that the link was basing mainly due to strong correlation to competitor orientation, whereas for bigger companies, the link between performance and market orientation was generally weak. Links between market orientation (mainly competitor orientation in the case of Ledwith and O'Dwyer) and new product performance was also supported by other studies (Ledwith and O'Dwyer, 2009; Wong and Tong, 2011; Matikainen et al., 2016), competitor orientation's importance also later confirmed by recent research (Wong and Tong, 2011; O'Dwyer and Gilmore, 2019). Altogether, the results show that market orientation is a strong driver to launch success; There are hints that market orientation serves as a driver to administrational proficiency and thus facilitates the establishment of an efficient launch strategy. Even more important for SME than for big companies, taken into account the limited resources of SME that must, as a consequence, also carefully be aware of the competitors' behaviour in order to take the right launch decisions. The suspicion that the corporate mindset, whether market-orientated or different, has an influence on new product performance, has been topic also of Kuhn (2007) with the result that management values and corporate mindset can positively affect new product success. Another study (Talke and Hultink, 2010) inspect the link between corporate mindset, launch strategy and new product performance on the basis of structural equation modelling, conclude that the corporate mindset has a significant effect on the efficiency and success of a new product launch strategy.

Close to the concept of market orientation is the approach of customer relationship management. According to Matikainen et al. (2015), relationship orientation "refers to an organizational culture that considers customer relationships a key driver of organizational performance". In this context, Matikainen et al. (2015) find out in their study that opinion leaders facilitate the adoption of new products in pharmaceutical industry. The study further examines wider correlations between tactical relationship launch measures like existing customer base, relationship orientation, marketbased assets such as strong relations to customers, and launch success. Thereby, the study distinguishes between the early adopters and the later majority of buyers. Thanks to these differentiations, the study can close gaps between former studies and allows to highlight a basis for tactical launch decisions in a time axis and split measures between pioneer users and the later majority. General result is that companies should focus on communication first to key opinion leaders and later to the majority of potential buyers, and see their customer relations and communication towards them as a key 
determinant of launch success. It also underlines the importance of relationship management to convince potential buyers of product advantages and explains why a focus only on market orientation and product development leads to suboptimal results.

\section{International Context}

Taken into account cultural differences, it might be easy to suppose that the product launch success factors and best practices differ from country to country. Indeed the question has been topic of some analyses as well. Lee et al. (2011) focus on differences between emerging markets, represented by Taiwan (97 companies) for the purpose of the study, and the US (284 companies) as an example for a mature market. The result of the study is that the choice of most tactical launch variables are constant for the US and Taiwan (e.g. the positive effect of the preannouncement, especially in emerging markets where customers are not familiar with the product), whereas some differ (e.g. in Taiwan, promotion price discount has a negative effect on customer satisfaction, whereas in the US, the opposite is correct as the market is mature). In mature markets and during product development phase, the authors propose to use more emotional advertising with a sense of humour, as customers loose the interest in already well-known facts, whereas informative advertising can work in emerging markets (Lee et al., 2011). However, it is dubious if the results from Taiwan could be generalized for all emerging markets taken into account the wide cultural differences, legal differences and other influence factors to other markets. Another disadvantage of the study is that the US sample has a much different size than the Taiwan sample which might affect the validity of the results. On the other hand, the study delivers practical implications for companies that want to launch products in an international context. Also, intercultural effects should be taken into account as the study shows clearly, that some of them exist indeed.

An even more substantial study by Calantone et al. (2011) of 261 companies in China and 183 in the US is conducted to show if success factors of the product launch differ from country to country. For this purpose, strategic and tactic launch variables that have been identified as key success drivers, are conceptualized and measured. The survey is overlapping with the work of Lee et al. (2011) in terms of "tactic launch variables" (Lee et al., 2011), which mainly appear as "launch execution" in the work of Calantone, di Benedetto and Song (2011). Also, both studies measure the product innovativeness as independent variable, whereas other variables differ. Finally, the study finds many similarities between the Chinese and U.S. empirical results (Calantone, Di Benedetto and Song, 2011). Differences were found concerning the effect of market orientation on timing which was lower in China. The effect of channel cooperation on launch timing was higher in China, and also the business resources effect on marketing activities execution was stronger in China. The biggest difference showed: the effect of business unit resources on performance was lower in China than in the U.S. The explanation of the authors for this phenomenon is that the state-owned companies in China do not depend so much on resources as these are provided by the government. However, results stay contradictory as another study concludes that market driven influences such as market orientation and product advantage, are more relevant in Asian firms than in Western firms (Huang and Tsai, 2013).

Whereas these quoted studies are based on empirical research based on correlation analyses, another approach is delivered by Bruce, Daly and Kahn (2007). The authors effect a case study of 2 examples in international launch: A leading manufacturer in kettle control systems who wants to launch a new hot-water filtration system in Europe; And a leading manufacturer of laminate flooring who conducts product launches in Europe and the US. The studies show that different markets have different requirements, e.g. different basis technology such as 5G and mobile network facilities; different colour tastes; the view on the product as "lifestyle product" or "product functionality"; and the use of language style for providing appropriate messages before the background of regional culture. As a consequence the article provides a good example for practical ways to adopt the (preparing) launch strategy and the launch tactics to local particularities. Finally, other examples for cultural differences and ways how companies could react to these differences by selecting adapted launch tactic variables, are given by a theoretical approach conducted by Căpățină (2014).

Altogether, it is clearly visible that the general success factors of launch appear also in the international context. However, it is necessary to study individual aspects of the target markets such as cultural and technological particularities. Also, even though success factors appear to have a strong input on performance, the way of their functioning can be different from market to market, as the different functioning of rebate prices in the US and Taiwan shows.

\section{The Launch Timing}

The timing of the launch, understood as right time schedule taking into account the matching within other activities like schoolings, promotion, channel communication and production, has been a neglected aspect. Calantone and die Benedetto (2012) conduct a survey about 183 US based companies to test a theoretical frame that shall highlight the influence of timing, lean launch and market orientation on new product performance. 
The study defines the optimal time as "selected with regard to the objectives of customers, distribution partners, and top management, and provides a competitive advantage" and calls this the "direct effect of launch timing". If the product is launched too late, other companies might take profit instead; if launched too early, the effect of advertising might be missing because the company fails to produce enough to cover demand, or the products might have defects. That is why there is also an indirect (moderating) effect of the timing: If the product is launched at the right time, the effect of marketing will also be higher. The study indeed confirms that there is a link between the right launch timing which moderates the effect of lean launch on the new product performance, whereas it apparently has no moderating effect on the quality of marketing measures. This can be explained by the fact that the measurement of the "right launch time" is seen related to a variety of factors (competition, customers, distribution channel, and business unit goals, coordination of measures), thus the effect on marketing execution could be measured not accurately enough. However the findings underline the importance of the right launch timing. Another study covers the aspect of the timing as well. The study of Calantone, di Benedetto and Song (2011) which was cited earlier, base on the same definitions of the right timing and could cite a strong link between new product performance and the right timing of the launch. That means, if the launch is effected with wrong channel coordination, missing coordination between marketing, production and launch, the overall success is thrown into question (Calantone and Di Benedetto, 2012). The timing itself is a result of coordination within the supply chain, so processes around logistics, production planning and the involvement of suppliers have been target of research as well. The cooperation within the supply channel (management aspect) has become a further focus of research.

\section{Cooperation Within the Supply Chain}

Today's times are characterized by a huge pressure due to increasing globalization and competition (Simon, 2012; Brynjolfsson and McAfee, 2014). Therefore, companies try to save resources. Cooperation projects can be a fitting strategy, also for product launch. An additional examination has been exercised about the link between cooperation via development alliances and new product success in the pharmaceutical industry (Talay, Seggie and Cavusgil, 2009): inspect data from 132 firms who participate in 66 new product alliances successfully and an additional number of firms who participated in failed products. They find that the combination of marketing (sales force, advertising and market research), technological and development abilities leads to more new product success if the alliance can invest much more resources into the project than the firm could do alone. The complementary of technologies in the participating firms had surprisingly no effect on success, which is explained by the authors with the presumption that within pharmaceutical industry, knowledge transfer between cross-technological competences is linked to barriers. In other sectors, this might be different. Even though lacking the claim of generalizability, the study shows that co-operations can lead to higher new product success.

This finding put ahead, other studies look more into detailed interrelations and can confirm the positive link between supply chain integration and new product success, for example Didonet et al. (2014). The influence of cooperation and the supply chain coordination on the launch success has been target of research effected by only two studies, namely Kou and Lee (2015) and Song, Song and di Benedetto (2011). Kou and Lee (2015) show that the cooperation within the supply chain (chain architecture) positively affects the new product performance, because it is a driver for lean launch strategies, wherever it does not have an influence on market share or customer satisfaction. (called marketing performance for the means of this study). However, the study reveals several problems. The study uses a definition for the "marketing"construct which is not commonly used. Whereas other studies see marketing as activities to achieve a market-orientated view inside of the company and respond to market needs, the study of Kou and Lee (2015) defines marketing performance as "market share and volume growth of a company", which are aspects that do not necessarily go back to a market orientated view inside of the firm. Also the term "supply chain architecture" which is used to describe one of the study's construct, is irritating if not altogether misleading. It is defined by the authors as "relationships between manufacturers and suppliers", whereas Supply Chain coordination is defined as "coordination and activity integration among supply chain members" (Kou and Lee, 2015). These definitions seem to overlap, which is a negative point of the study as the survey model is not clear as a consequence. Also, the focus on high-tech industry is a limit to transfer findings of the study to other markets, as the characteristic of high-tech industry is quite particular. However, the result that cooperation with suppliers can boost lean launch und product performance seems to be out of question.

Another study (Song, Song and di Benedetto, 2011) investigates first new product performance in recently established "ventures" where suppliers have been engaged. The investigated question is, if supplier engagement leads to higher new product performance, where supplier specific investment is defined as "the extent to which the major supplier tailors its production system to the requirements of the new venture, invests significant resources to 
fit with the new venture's production capabilities, purchases specialized tools and equipment, and sets unusual technological standards for its production”. The study uses a complex model which also inspects the link between marketing, launch activities, product innovativeness, R\&D expenses and new product performance of new ventures. The result is that a good launch execution (launch quality) including timing and supply chain management is more decisive for product performance than an innovative product; Also, investment in marketing does not affect innovativeness and new product performance, which is a surprising result (Song, Song and di Benedetto, 2011). However, it has a positive impact on launch execution. The part of the supplier also boosts new product performance through its contribution to an innovative product. But as cited, the effect of launch execution is stronger. Based on the results, the authors recommend an "appropriate pricing strategy, develop high quality promotional programs, and provide on-time delivery and quick response to customer requests" in order to obtain new product performance. Although the results of the study seem comprehensible, it reveals some weaknesses. The term "ventures" is irritating in this study, because other studies mainly use "firms", "organizations" or "companies". It is not very clear if in this context the authors examine "joint ventures" as an organization form between companies, or "firms". As they cite the lack of resources from which new "ventures" suffer, it seems to be "firms" that they are writing about. In this study, some terms are again used with overlapping aspects to other studies, but also not in total congruity. For example, instead of "launch execution" (Calantone, Di Benedetto and Song, 2011) this study uses the construct "launch quality" to describe more or less the same. The new product performance is measured differently to other studies, namely by firm's gross margin and sales growth rates. This is due to the fact that the new product turnover and margin is the only variable that moderates turnover of a new venture and thus logically comprehensive. Also, with 711 participating new product projects, the study benefits from a comparably large set of data. The generalizability of the study must nevertheless be put into question, as it has been linked only with new ventures which have organizational particularities. However, the results concerning the importance of timing and pricing, for example, or the dubious aspect of innovativeness, are in correlation to the results of other studies. The supposed link between weak influence of launch execution measures on new product performance and insufficient supply chain coordination is also confirmed by a third study. Schoenherr and Swink (2015) make a survey on 229 American firms to find out about the interdependencies between the proficiency in sharing knowledge between the partners within the supply chain (construct that they call "supply chain intelligence integration"), supply chain adaptability (which is defined by the authors on behalf of an older study as "a dynamic capability that enhances a firm's ability to integrate, build, and reconfigure internal and external competencies to address rapidly changing environments and new product performance. In accordance with the other studies, the authors can prove that the capacity-, process-, and materialoriented supplier input (supplier intelligence) does not affect product innovation capability, but the companies' abilities in supply chain adaptability. Company's product development skills are more influenced by customer and competitor intelligence. In the end, supply chain adaptability and supply chain intelligence integration both foster new product performance. The study is thus some further evidence of the importance of logistics and cooperation within the supply channel.

\section{Resources}

An early and intuitive assumption concerning the launch success factors has been that the resource equipment is boosting and essential for launch success. The resource aspect has not been main topic of recent studies but it appears as side factor in various studies. Song, Song and di Benedetto (2011) find that marketing resources and marketing capabilities driving the new product development process (Kim, Shin and Min, 2016) provided to the product launch, help to increase new product performance, confirmed also by another study (Kyriakopoulos, Hughes and Hughes, 2016) that creates a link between relational resources and launch success. Kuhn (2007) finds an indirect link, as the management support given to the launch team, has a positive impact on the new product success. The study of Calantone, Di Benedetto, and Song (2011) and Millson (2012) find links between business unit resources, launch execution/ new product development performance and new product performance. Together with the conclusions from the other mentioned studies and topics, it seems to be logical to conclude that the resource equipment is a success factor but the resources should at first be invested into the execution of launch measures, timing and coordination. This is why mainly small companies lacking resources, should refrain from investing in innovative products, but into launch measures in potentially good markets before. However, the studies reveal also hints that marketing skills and the use of marketing resources should already be used in the development phase in order to adapt the product to the needs of the market.

\section{Market Attractiveness}

Song, Song and di Benedetto (2011) show that with a big market potential, more expenses in $R \& D$, 
marketing and launch execution, lead to more new product performance, whereas more expenses in $\mathrm{R} \& \mathrm{D}$ to develop a highly innovative product, does not lead to higher product performance. This conclusion is intuitive when you conjure that new product performance is a result of turnover and cost, and with limited sales due to an unattractive market, success is not easy to obtain. Kuhn (2007) provides evidence that the market potential has a positive effect of the new product performance, whereas the intensity of competition has a negative effect. The results seem to be logical and a congruity between the two studies is intuitive. Another study (Fraenkel, Haftor and Pashkevich, 2016) is, among other factors, concerned with finding the optimal market proprieties - launch success pattern and reveals that in the pharmaceutical industry, successful launches occur the more if the market is instable and turbulent. The result could be transferable to other markets, because it seems to be logical that under situation of uncertainty, customers are more open to new products as they are used to change.

\section{Different Product Categories}

An additional question discussed in literature has been the role of the product category. In this context, one study (Talke and Hultink, 2010) also provide interesting information about interdependence between market proprieties (market turbulence high/low), technological turbulence (high/low), product proprieties (high/low complex) and the right launch tactics. The study finds that under high turbulence (defined as "uncertainty exists related to the stability of technological trends, market developments, competitive structures, or customer demands), measures towards the stakeholders in order to diminish adoption barriers are more relevant. If the product is also complex, barrier-reducing measures towards an even wider range of stakeholders comprising the internal and external company environment, inclusive dealers, becomes important. However, the study cannot be generalized as it concerns mainly complex industrial goods, where the role of traders and sales forces is totally different than in consumer markets.

Another attempt to find clusters based on market and product proprieties has been conducted by Kuhn (2007). The study uses other criteria for the clusters and finds that product launches in high-potential markets, effected with a highly advantageous product and supported by highly proficient measures, are very successful. Products that are not really new (compare "less complex products" in the study of Talke and Hultink) do not require lots of preparation measures like schoolings, resource allocation etc of the management (the result is congruent with the lower need of barrierreducing measures found in the study of Talke and Hultink). Other categories in the study of Kuhn are not comparable to the study of Talke and Hultink, because the categories are mainly defined by price advantage, product newness, market drivenness of the product and management involvement into the launch. Kuhn (2007) comes to the conclusion that the more the product is advantageous and sold with more commitment into planning and launchexecution by the management, the more the launch becomes successful. If the launch is conducted without management commitment and the product is not advantageous, the success level is low.

Some aspects of the 2 studies are coherent and underline the importance of the product and market proprieties. The studies also show that product proprieties, market proprieties and launch tactics determine the optimal launch tactic measures.

\section{Other Phenomena}

Ahearne et al. (2010) conduct a survey to find out about the link between product proprieties, control systems and the sales force behaviour. Based on interviews with 226 experts and 428 customers in the pharmaceutical industry, the authors effect structural equation modelling and find that the sales forces tend to avoid investment into innovative products because they assume that these products sell on their own. Sales people tend to invest time in efforts to sell more difficult products because they assume that these products need more investment from their side. The role of a company's remuneration system should be aware of that effect.

In accordance with the Ahearne-study, Fraenkel, Haftor and Pashkevich (2016) examine the influence of several sales force factors concerning new product launch success. The factors inspected, according to the authors, are target-setting for the NPL process, recruiting and selecting appropriate sales representatives, providing sales processes, information processes and training; and choosing appropriate reward schemes and control modes. The study examines 68 product launches in pharmaceutical industry in Sweden and finds that the personality of the salesman has a high influence on the project success, as well as the compensation system. Also, a working system which is well defined, but nonetheless leaves a high degree of freedom to the sales people, showed to be the most successful. Also, a successfully launched new product was "detailed by the sales representatives in a stand-alone mode, rather than jointly with other products" (Fraenkel, Haftor and Pashkevich, 2016).

Cetinkaya and Thiele (2016) develop a computer simulation model based on the Bass diffusion model. The target of the model is to handle uncertainty regarding buyer's preferences. If a company has to launch several products which differ in terms characteristics which are relevant for adoption, management has to estimate the sequence of launch. Therefore, the model is an assisting tool which helps management to optimize 
profit. However, as results coming from the model have not yet been tested empirically, the usability for management has to be put into question.

Jhang, Grant and Campbell (2012) conduct four surveys to find out about psychological effects around perceived incongruity (e.g. like Whisky with lemon flavour) and the product adoption. Basing on 348 experiments, the authors find out that perceived incongruity is hindering adoption. Measures to prevent perceived incongruity can be taken by advertising and communication. The authors find out that communication measures like creating positive effects, future framing and providing alternative explanations for a situation can diminish perceived incongruity and facilitate adoption. The study is a worthwhile article that can enrich advertising strategies around new products.

Findings about how to react on competitors' actions are delivered by Wang and Shaver (2016). The study is based on 1860 observations of Chinese TV broadcasting companies. Therefore, the TV program is analyzed to find out if TV stations reposition the programme to avoid competing or launch new products after according activities of the leading competitor. The study touches the topic of new product launch only at the brink. Also, it is dubious whether the results from China are easily generalised to other markets. Also, the study only shows current behaviour of some companies, but does not provide implications how to take better decisions.

Whereas lots of current studies cover tactical aspects of the product launch, another study (Panwar and Bapat, 2007) treat strategic issues linked to the question if line extensions, brand extensions or new brands are the most successful launch projects. Therefore, the study has to refocus on the elementary strategic requirements that create launch success and have widely be topic of discussion in the 80s and 90s of the last century, referring to considerations like push or pull strategy, product differentiation, or developing a unique channel structure. The study could find proof for the assumption that line extensions are more successful than brand extensions; The study also underlines the importance of product availability which is congruent with other studies cited in this article (e.g. Calantone, di Benedetto and Song, 2011; Calantone and die Benedetto, 2012; Song, Song and di Benedetto, 2011). Pull factors (consumer acceptance and brand awareness) have a higher influence on launch success than push factors (price, promotion). The study is limited by the fact that the scope is focused on distributers, so the results are only applicable in a similar environment. Also, a clear table of contents showing the results of the hypotheses is unavailable, the analysis of the results is only possible based on the statements of the authors. However, the study reveals strategic aspects in the limited field of product launch strategies before the background of trade channels and brands involved.

Another approach is driven by Cui, Zhao and Ravichandran (2011). Based on a theoretical approach, the authors develop a proposal of a system dynamics modelling for new product launch process, including marketing and supply chain variables. Particularity of the model, especially towards the static Bass model which it amplifies, is that it simulates the dynamic interactions among pricing, advertising, channel development, manufacturing and inventory management. Thus it is useful to be applied as a simulation tool for launch managers. However, it is a simplification of reality and basis on logarithm logic e.g. to calculate price elasticity effects. Thus the model must still proof whether it is able to describe reality cases.

Jiang, Qu and Jain (2018) develop a generalized multigeneration diffusion modelling Framework simulation to find theoretical optimization of launch sequence in software and computer industry. The question they like to answer is, when the best time for launching a new product generation would be. The work achieves theoretical results about the optimal time, but further inquiries would be necessary to test these assumptions in reality.

Based also on a theoretical approach involving game theory, Lobel et al. (2015) conduct research about which launch strategy of generic product generations maximizes profit, especially if strategic consumers discount their expectations about price and technologic advantage from product generation to generation. The main result is that a 2-launchcycle with one minor innovation advance and then one major innovation advance, maximizes companies profit taking into account strategic buying attitudes of consumers. Even though results appear very interesting before the background of decision taking and game theory, the simulation has to take many simplifying hypotheses, like a monopolistic firm or homogenous/heterogeneous consumers. Also, strategic behaviour adopts if the counterpart changes his behaviour. Therefore, the results of the studies are only of limited use.

Caldieraro, Kao and Cunha (2015) try to answer a strategic question regarding the decision to launch additional products as extensions within an existing product line in order to prevent potential buyers from buying a competitor's product. These extensions can be downward extensions (cheap products that have the risk that buyers would buy this product instead of the expensive one) or upward line extensions (premium products). If a challenging company launches a new product based on other product advantages or technologies, the challenged company might be tempted to launch a "better" product with the same attributes in order to thwart the desired effect of the competitor. The authors develop a model and test it empirically to 
find out if this behaviour is reasonable. They find out that by launching a premium product that shall have the same technology or advantages as the competitor's product, companies can unfortunately cause positive consumers' perception even for the competitor's product, and thus undermine the own strategic position which results in decreasing market share and sales figures. It is only recommendable to launch a premium product if it has expected spill-over effects on the parent brand, not on a cross-brand (in other words, if it strengthens the parent product characteristics, not the competitor product's characteristic). The study gives support for strategic launching decisions before a competitive background and provides helpful information about buying behaviour of consumers when a brand line is involved.

Before the background of stakeholder theory, Talke and Hultink (2010) conduct research about adoption barriers. The process of successfully launching a new product can be understood as overcoming adoption barriers. In the past, research has focussed on the question which tactical launch measures effectuate this target at potential buyers. The study of Talke and Hultink (2010) also contains an examination of other stakeholders, namely dealers, suppliers and competitors and refers to different market circumstances such as technological turbulence, market turbulence, and product complexity. A weakness of the study is that it does not distinguish between different launch tactics in the tested hypotheses even though only communication and cooperation is meant. Concerning barrier measures towards competitors, the study that a co-operative approach that combines at the same time cooperative and competitive behaviour towards the competitor, influence the market success of a new product positively. The strongest correlation is between diminishing diffusion barriers towards customers and suppliers. In general, these results can be seen as a confirmation of previous studies who also underline the importance of launch tactics towards potential customers, and of cooperative involvement of suppliers.

The impact of promotion on sales, and similar topics concerning the adoption process in the product launch phase has been analysed by some authors (Talke and Colarelli O'Connor, 2011; Talke and Snelders, 2013; Frattini et al., 2014; Burmester et al., 2015). Burmester et al. (2015) conduct a study about the sales effects of pre-launch and post-launch effects in a wide sample of video games, overall about 3.336 games and 86.000 observations about promotion, advertising and sales data in Germany. Their study measures the increase of sales due to advertising or publicity (advertising- and publicity elasticities). The study reveals that pre-launch publicity (elasticity $=0.21$ ) is much more efficient than pre-launch advertising (elasticity 0.11). In the post-launch phase, both publicity and advertising effects are less strong, but advertising has about the same effect as publicity. The study also shows that in the pre-launch phase, publicity and advertising have an antagonistic effect, whereas in the post-launch phase, this is not the case (Burmester et al., 2015). The analysis allows to adopt to contingent the promotion expenses according to these findings and have different weights in the pre-launch and post-launch phase. As the data on which the study bases, is very wide, the findings of the study can be seen as relevant. However, the video game market is particular and not comparable to many other markets. For example, video games are a consumer product, where the purchase decision is influenced more by emotions and attitudes than in the B2B, where purchase decisions are taken by rational product advantages. The market is described by the authors as very turbulent with lots of new product launches, which means that results might not be comparable to other markets with different product- or market characteristics. However, it reveals interesting results of the effect of advertising and publicity, which can be used in similar markets. The assumed positive effect of advertising has been also confirmed by a further study about the link between the use of online advertising and social media communication and the six months launch success in a study of 122 durable good firms (Gruner et al., 2019), concluding that both social media communication and online advertising have a positive effect, which is U-shaped in the case of advertising. The positive effect of social media and online-marketing measures could be confirmed in other studies (Cui, Lui and Guo, 2012; Kumar et al., 2016; Schildmann, Bendig and Brettel, 2019; Busca and Bertrandias, 2020). Linked to the difference between radical innovations and incremental innovations, the study of Frattini, Dell'Era and Rangone (2013) shows that the launch tactics concerning communication, cooperation within the sales channel by involving external organizations into the launch measures, and corporate advertising differ between radical innovations and incremental innovations. For advertising, the communication of distinct characteristics is important for radical innovations to reduce perceived purchase and switching risks, whereas for incremental innovations, corporate advertising is more effective to catch awareness towards the new product.

\section{Future Tendencies}

A look at today's discussion of the topic of product launch is the question of which current trends the topic is subject to and which future changes of best practices are to be expected in order to achieve success in practice with the product introduction of new products. Against this background, megatrends that influence and perhaps modify the relevant influencing factors are important. 
There is a general consensus in the scientific community as to which current megatrends influence economic life today and in the coming years. Above all, these are globalisation and digitisation (Kämpf and Boes, 2010; Simon, 2012; Brynjolfsson and McAfee, 2014). Globalization describes the growing together of regionally and culturally different regions to form an entire, global system. Digitalisation describes the mapping of wide areas of life in virtual structures and systems generated by binary code in computer programs (Gumm and Sommer, 2009; Wahrig Herkunftswörterbuch, 2019). These systems are increasingly autonomous, self-learning, smart and networked (Gerst, 2019). This enables them to play an ever greater role in everyday working life, to make tasks more efficient and effective, and to supplement or even replace people in increasingly demanding tasks (Boes et al., 2018). The combination of the two megatrends will lead to three further megatrends: hyper-competition, mobility and networking.

The effects of these megatrends on the world of work are referred to by experts as the fourth industrial revolution and are called "Industry 4.0" in German (Dombrowski, Riechel and Evers, 2014; OECD, 2017; Oleff and Malessa, 2018; Seiter et al., 2016). This is in accordance with and logical continuation of the generally accepted earlier general upheavals of the working environment, which were triggered by the invention and widespread use of the steam engine (first industrial revolution), mass production and electrification (second industrial revolution) and the widespread use of computers (third industrial revolution) (Simon, 2012; Brynjolfsson and McAfee, 2014).

Which of these trends have an impact on bestpractice methods of product launch? When markets grow together thanks to globalization, this undoubtedly results in the expansion of the offer to a global context. Other customer markets on other continents and with different cultural backgrounds are coming more to the fore. However, as already cited studies have shown, the success factors of the market launch that have already been identified remain valid in an international context. Apart from the already necessary modifications of the general business transaction, if one wants to be internationally active, no further special influences are to be observed.

Hyper-competition (D'Aveni, 1995) must be seen against the background that global networking and digitisation technologies (Internet, mobile telephony, self-learning systems) are capable of distributing successful and revolutionary products and business models across the globe in real time (Kreutzer, 2016). A large part of the business models that have emerged in recent years are also virtual (e.g. the Amazon trading platform) without the capital commitment associated with material business models. The latest evaluation of the world's most valuable brands by Brand Finance showed that the top seven places are now occupied by companies from the ICT sector (BrandFinance, 2019). As the researcher D'Aveni has recognised, it is therefore logical that hyper-competition should be characterised by an acceleration of the emergence and decay of competitive advantages of established providers and by the orientation of measures towards the customer and his needs (D'Aveni, 1995). The intensification of competition leads to the fact that the achievement of competitive advantages, which today disappear faster than before, is replaced by the goal of destroying competitors. In this scenario, the business models of existing companies are increasingly threatened by aggressive new competitors. All they can do is adapt their business model and their product portfolio through innovation. However, innovation is risky and, as already argued, its likelihood of success is uncertain in any case. Against this background, the most important strategic question regarding the market launch in the $21^{\text {st }}$ century is: What strategies and techniques make a significant contribution to reducing the risk and costs of innovation and market introduction in general, and to increasing the effectiveness and probability of success of new product launches?

Digitisation provides a convincing answer to this question. It is not only a megatrend and thus a source of threats to the livelihood of companies, but also a source of possible solutions. The high potential of digitisation for increasing effectiveness and efficiency in administrative processes is repeatedly demonstrated by empirical examples (e.g. Boes et al., 2018; Etventure, 2018; Will, Campbell and Holmes, 2015). Self-learning systems and efficient computer programs support all areas of the company involved in organization, processing and development (Boes et al., 2018; Gerst, 2019). The Internet also offers the opportunity to conduct market research and communicate news in real time (Bernard, 2016; Kreutzer, 2016).

Digitisation is high on the global agenda according to the OECD Digital Economy Report 2017. In the course of digitisation, most authors describe the following uniform trends, which are likely to influence market launch practice in particular:

- The performance of computer systems is growing exponentially (OECD, 2017; Boes et al., 2018; Gerst, 2019). In combination with AI and selflearning software, the range of products is therefore becoming increasingly diversified and available on the market faster and faster thanks to Industry 4.0. ITC technologies allow new products and technologies to spread around the world and diffuse into the market rapidly (Diermeier and Goecke, 2017). The needs of customers are thus becoming increasingly special and individual (Leisse, 2014). Other technical features linked 
to digitalization will be applicable to improve launch performance, for example such as direct digital manufacturing (Khajavi et al., 2015).

- Big Data: The analysis of customer needs is therefore becoming increasingly important in order to create offers that are rewarded by customers. The collection of large amounts of data requires big data applications that are capable of collecting and evaluating this data (Gerst, 2019). Market research becomes an essential part that accompanies a market launch.

- A study by Ernst\&Young (Ernst\&Young, 2018) showed that the majority of companies are already using digital sales channels to reach their customers, with an increasing tendency. Unlike in the past, the logic on the Internet is decentralized and networked. Communication takes place between customers on platforms, as in the past between the company and the customer. Companies must take this type of communication into account in their market introduction policy. One possibility for this is influencer marketing passing opinion leaders (Matikainen et al., 2015; Pleil et al., 2017).

- An intense study shows that size matters less than productivity focus in order to take profit from digitalization. Digitalization enables also SME to link advantages of speed, scale and scope (Gal et al., 2019). With more powerful digital tools, successful companies will be able to identify trends more quickly, bring them to market and communicate them, and, as a consequence, gain effects of scale. The speed with which market shares are gained and the extent of profit can already be almost limitless today. To keep pace, companies must use these tools to become more innovative and take advantage of the economies of scope.

However implications might be drawn from this information, one thing is clear: Digitalization will in any case affect the procedure and success factors of product launch. Despite the enumerated expectations, growing productivity due to digitalization is not an undisputed phenomenon, as productivity growth worldwide seems untouched by digitalization and is even stagnating since two decades (van Ark, 2015; Frey and Osborne, 2017). Studies conclude that implementing digitalization within an organization, requires deep investment into intangible assets (van Ark, 2015; Gal et al., 2019). Digitalization itself seems to be a risk, if not properly managed. Therefore, the author detects a widening gap on science concerning the implications that digitalization delivers for new product launches. Until now, there is not yet any known study which focuses on research concerning this topic.

\section{DISCUSSION}

The results of the review show that nowadays, the subject of new product launch has widely been studied. The research published in the last 15 years, already included wide knowledge of studies conducted in the last 30 years before which mainly concern the success factors. This explains why most of the papers published since 2005 take place from a global perspective. They offer complex models of success factors that have crystallized already before and try to validate these factors and their relations among each other. In most of the cases, success factors could be confirmed, even though many studies reveal surprising details even nowadays.

It could also be shown that some results are contradictory even today. Research requirement is still to be done on the interactions between new product success, the effect of launch execution, the role of the product advantage and supply chain management. It is a problem of the current status quo of research, that definitions of terms are not yet used of sufficient congruity. Therefore, contradictions as mentioned in section 3.2, can occur. However, concerning success factors of the product launch, the current science reveals already a wide and reliable basis in general.

Research has partly also focussed on different product types (B2C/B2B), different product characteristics (e.g. toys, computer, hightec...) and company size (SME/big companies). But most of these studies see these topics not as an independent and prior field of their research. They only create results on that question randomly, because these conclusions are found as explanations for results found in a cluster analysis. As most of the studies are small (200 participants), results tend to not be enough validate to generalize them. Further research is needed to deepen findings about differences between these mentioned types of companies and goods. A perspective on B2B c-parts is lacking totally, for instance.

Concerning international differences, the scientific background is also providing some results about differences and similarities. Unfortunately, most of the literature concerns only a few countries like US, Europe, China and Taiwan. It would be fruitful to conduct similar approaches for countries in other cultural spheres.

Apart from the wide field of success factors, product launch literature leaves several doors wide opened. Until today, an all-embracing approach would be necessary. Taking into account the importance of new product launch, it would be well appreciated by scientists and also practitioner, to have an overview about all questions around new product launch that can be used like a manual, applicable for all kind of goods, markets, business and companies. In order to reach at this point, some further questions are still unanswered: Most findings are collected in a limited part of the market. 
Can they be transferred to other sectors? Therefore, a reasonable system providing an overall overview about all relevant product and market categories in order to visualize the scientific gaps would have to be developed, using criterias such as the product category (B2B/B2C); the company's supply chain status (Supplyer/product manufacturer), different product markets (e.g. chemicals, consumer goods, automotive supply parts, and so on); Country background (Country or cultural region) and Company sizes could serve as criteria.

Therefore, another sector of research has been neglected totally: The best practice perspective, which takes a process-oriented view. New product launch is, above all, a process. All discussion about success factors and differences between companies, are until now led from the point of view of decision taking. Decision taking needs process standardization and to follow a path which, until now, is totally unlighted by scientific research up to now. Existing literature coming from new product development could be used as a preceding starting point for a development of a new product launch best practice approach.

Finally, new tendencies of current megatrends, mainly the digitalization, should be studied in order to derive implications and to-do-recommendations. Also here, no significant research has been found which would treat that important subject.

\section{CONCLUSION}

The current literature on new product launch disposes about a deep knowledge basis, especially concerning the launch success factors of various kinds of businesses, companies and countries. It is clearly to be seen that the optimal launch decision is a depending variable on a manifold mix of numerous situational variables. As of now, no complete overview over the complex material exists, some results might look contradictory and even incomplete. Furthermore, the current results suffer from limited comparability. Whereas it is more or less clear, which general success factors and input factors influence product launch, in detail the results do not show a complete picture about differences between product markets, company sizes, and other specific indicators which create differences of launch factors. Some of the analyzed studies show that the success measures and the success level differs between B2C and B2B markets, international countries, product categories and company sizes. Further research would be needed here, and it would be helpful to propose a general system of differentiation. For example, cases could be differentiatied by target markets with appropriate indicators such as culture (Europe, Africa...), company size, company age, strategic category for final user (product is strategic, or non strategic), B2B or B2C, sales channel (target customer = trader, target customer $=$ user), product category (complex, simple, high-tec,) and so on.

Managerial implications can similarly be drawn. Due to the high number of studies and the long time in which the subject of product launch has been research topic, fundamental results of how success can be generated, are already manifest. Managers can use these findings to reduce failure rates and increase success probabilities. However, especially for practitioners, the current requirements stay unsatisfactory. Despite the large number of validated effects, still a perspective that creates the big-picture, is missing. Previous research has analysed a great number of singe effects and isolated interdependencies. For management, which is a highly connected ad holistic discipline, the results are not enough consolidated to create the big picture.

It gets also clear that questions around the launch of new products must be seen from a strategic point of view, and are decisions under uncertain conditions. Therefore, the current status quo of literature, once put together as a "big picture", could provide deep knowledge and help in these strategic launch decisions.

However, still some weaknesses concerning methodology, comparability and scientific gaps could be found.

Taking into account the importance of that subject, it would be recommendable to close existing research gaps and focus on new themes like best practices, comparisons between different company types, businesses, products and markets; the process perspective; and the impact of digitalization on the subject. The aspect of digitalization reveals another important aspect, as the digitalization could cause a cultural change of customers' behaviour, customers tastes, distribution channels and communication. Also existing findings could become target of further research, as the current findings base on small studies. In order to confirm findings, it would be useful to validate them additionally or use bigger samples.

The aspect of digitalization reveals another important aspect, as the digitalization could cause a cultural change of customers' behaviour, customer tastes, distribution channels and communication. It is as a consequence necessary to inspect the influence of digitalization on the launch process and success factors. The author of this work plans to organize further research on this topic. It is expected that digitalization will provide additional tools which can reduce product launch cost, raise the 
effectiveness of launch tactics, support launch strategy with big data analyses and decrease measure costs. On the other hand, digitalization is a driver of competitive pressure, as customer expectations and competition will increase. Based on today's situation, the author plans to empirically answer the question, which impact digital tools have today on the product launch success in SME.

For researchers, the current obtained status is already a large body of knowledge, but still provides opportunities of research. For the interested practitioner, the current status delivers already a deep insight of knowledge and decision-helping facts.

\section{REFERENCES}

AHEARNE, M., RAPP, A., HUGHES, D. and JINDAL, R. 2010. Managing Sales Force Product Perceptions and Control Systems in the Success of New Product Introductions. Journal of Marketing Research, 47(4): 764-776.

VAN ARK, B. 2015. Productivity and Digitilization in Europe: Paving the Road to Faster Growth. Digiworld Economic Journal, 100: 107-124.

BERNARD, M. 2016. The impact of social media on the B2B CMO. Journal of Business \& Industrial Marketing, 31(8): 955-960.

BHALLA, M. 2013. Waterfall versus sprinkler product launch strategy: Influencing the herd. The Journal of Industrial Economics, 61(1): 138-165.

BOCCONCELLI, R., CIOPPI, R., FORTEZZA, F., FRANCIONI, B., PAGANO, A., SAVELLI, E. and SPLENDIANI, S. 2018. SMEs and marketing: a systematic literature review. International Journal of Management Reviews, 20(2): 227-254.

BOES, A., KÄMPF, T., LANGES, B. and LÜHR, T. 2018. »Lean« und»agil im Büro: Neue Organisationskonzepte in der digitalen Transformation und ihre Folgen für die Angestellten. Bielefeld: Transcript Verlag.

BRANDFINANCE. 2019. Global 500 2019. The annual report on the world's most valuable and strongest brands. [Online]. Available at: https://brandfinance.com/images/upload/global_500_2019_locked_1. pdf [Accessed: 2019, August 27].

BROCKHOFF, K. 2010. Forschung und Entwicklung: Planung und Kontrolle. München: Oldenbourg Verlag.

BRUCE, M., DALY, L. and KAHN, K. B. 2007. Delineating Design Factors that Influence the Global Product Launch Process. Journal of Product Innovation Management, 24(5): 456-470.

BRYNJOLFSSON, E. and MCAFEE, A. 2014. The Second Machine Age: Work, Progress, and Prosperity in a Time of Brilliant Technologies. New York: W. W. Norton \& Company.

BURMESTER, A. B., BECKER, B. U., VAN HEER, H. and CLEMENT, M. 2015. The impact of pre- and post-launch publicity and advertising on new product sales. International Journal of Research in Marketing, 32(4): 408-417.

BUSCA, L. and BERTRANDIAS, L. 2020. A Framework for Digital Marketing Research: Investigating the Four Cultural Eras of Digital Marketing. Journal of Interactive Marketing, 49: 1-19.

CALANTONE, R. J. and DI BENEDETTO, C. A. 2007. Clustering product launches by price and launch strategy. Journal of Business \& Industrial Marketing, 22(1): 4-19.

CALANTONE, R. J. and DI BENEDETTO, C. A. 2012. The role of lean launch execution and launch timing on new product performance. Journal of the Academy of Marketing Science, 40(4): 526-538.

CALANTONE, R. J., DI BENEDETTO, C. A. and SONG, M. 2011. Expecting Marketing Activities and New Product Launch Execution to Be Different in the U.S. and China: An Empirical Study. International Journal of China Marketing, 2(1): 14-44.

CALDIERARO, F., KAO, L.-J. and CUNHA, M. 2015. Harmful Upward Line Extensions: Can the Launch of Premium Products Result in Competitive Disadvantages? Journal of Marketing, 79(6): 50-70.

CĂPĂȚîNĂ, G. 2014. The Influence of Culture on Marketing Programs for New Products Launch. SEA - Practical Application of Science, 2(3): 175-184.

CAPATINA, G. and DRAGHESCU, F. 2015. Success Factors of New Product Launch: The Case of iPhone Launch. International Journal of Economics and Finance, 7(5): 61-70.

CETINKAYA, E. and THIELE, A. 2016. New product launch decisions with robust optimization. Computational Management Science, 13(2): 263-292.

CHEN, C.-W., SHEN, C.-C. and CHIU, W.-Y. 2007. Marketing communication strategies in support of product launch: An empirical study of Taiwanese high-tech firms. Industrial Marketing Management, 36(8): 1046-1056.

CHO, H.-J. and PUCIK, V. 2005. Relationship between innovativeness, quality, growth, profitability, and market value. Strategic Management Journal, 26(6): 555-575. 
COOPER, R. G. and KLEINSCHMIDT, E. J. 1988. Resource allocation in the new product process. Industrial Marketing Management, 17(3): 249-262.

COOPER, R. G., EDGETT, S. J. and KLEINSCHMIDT, E. J. 2004. Benchmarking Best NPD Practices-I. Research-Technology Management, 47(1): 31-43.

COURTY, P. and NASIRY, J. 2016. Product launches and buying frenzies: A dynamic perspective. Production and Operations Management, 25(1): 143-152.

CUI, A. S., ZHAO, M. and RAVICHANDRAN, T. 2011. Market Uncertainty and Dynamic New Product Launch Strategies: A System Dynamics Model. IEEE Transactions on Engineering Management, 58(3): 530-550.

CUI, G., LUI, H.-K. and GUO, X. 2012. The Effect of Online Consumer Reviews on New Product Sales. International Journal of Electronic Commerce, 17(1): 39-58.

D'AVENI, R. A. 1995. Coping with hypercompetition: Utilizing the new 7S's framework. Academy of Management Perspectives, 9(3): 45-57.

DIDONET, S. R., FREGA, J., TOALDO, A. M. and DIAZ, G. 2014. The role of supply chain integration in the relationship between market orientation and performance in SMEs. International Journal of Business Science \& Applied Management (IJBSAM), 9(2): 16-29.

DIERMEIER, M. and GOECKE, H. 2017. Productivity, Technology Diffusion and Digitization. CESifo Forum, 18(1): 26-32.

DÖLLGEN, H.-J. 2018. Global und digital - Wirtschaftssenatoren in Weiherhammer. Der Mittelstand, 18(3): 100

DOMBROWSKI, U., RIECHEL, C. and EVERS, M. 2014. Industrie 4.0-Die Rolle des Menschen in der vierten industriellen Revolution. Industrie, 4: 129-153.

ENIS, B. M., LA GARCE, R. and PRELL, A. E. 1977. Extending the product life cycle. Business Horizons, 20(3): 46-56.

ERNST \& YOUNG. 2018. Digitalisierung im deutschen Mittelstand. Available at: https://www.ey.com/ Publication/vwLUAssets/ey-digitalisierung-im-deutschen-mittelstand-maerz-2018/\$FILE/eydigitalisierung-im-deutschen-mittelstand-maerz-2018.pdf [Accessed: 2020, November 15].

ERNST, H. 2002. Success Factors of New Product Development: A Review of the Empirical Literature. International Journal of Management Reviews, 4(1): 1-40.

ETVENTURE. 2018. Studie Digitale Transformation 2018. Available at: https://service.etventure. de/hubfs/etventure_Studie_2018-Trendreport.pdf?hsCtaTracking=52ea00ef-e9c3-40f2-9e375e6fd18cd301\%7C75ddf2ef-585d-4792-a44b-95534b2b1a86 [Accessed: 2020, November 15].

FRAENKEL, S., HAFTOR, D. M. and PASHKEVICH, N. 2016. Salesforce management factors for successful new product launch. Journal of Business Research, 69(11): 5053-5058.

FRATTINI, F., BIANCHI, M, DE MASSIS, A. and SIMIC, U. 2014. The role of early adopters in the diffusion of new products: differences between platform and nonplatform innovations. Journal of Product Innovation Management, 31(3): 466-488.

FRATTINI, F., DELL'ERA, C. and RANGONE, A. 2013. Launch Decisions and the Early Market Survival of Innovations: An Empirical Analysis of the Italian Mobile Value-Added Services (VAS) Industry. Journal of Product Innovation Management, 30: 174-187.

FREY, C. B. and OSBORNE, M. A. 2017. The future of employment: How susceptible are jobs to computerisation? Technological Forecasting and Social Change, 114: 254-280.

GAL, P., NICOLETTI, G., RENALUT, T., SORBE, S. and TIMILOTIS, C. 2019. Digitalisation and productivity: In search of the holy grail-Firm-level empirical evidence from EU countries. OECD Economics Department Working Papers No. 1533. Paris: OECD Publishing.

GERST, D. 2019. Autonome Systeme und Künstliche Intelligenz. In: Autonome Systeme Und Arbeit. Perspektiven, Herausforderungen Und Grenzen Der Künstlichen Intelligenz in Der Arbeitswelt. Bielefeld: Transcript Verlag, pp. 101-138.

GORMAN, G., HANLON, D. and KING, W. 1997. Some research perspectives on entrepreneurship education, enterprise education and education for small business management: a ten-year literature review. International Small Business Journal, 15(3): 56-77.

GREEN, D. H., BARCLAY, D. W. and RYANS, A. B. 1995. Entry Strategy and Long-Term Performance: Conceptualization and Empirical Examination. Journal of Marketing, 59(4): 1-16.

GRUNER, R. L., VOMBERG, A., HOMBURG, C. and LUKAS, B. 2019. Supporting New Product Launches With Social Media Communication and Online Advertising: Sales Volume and Profit Implications. Journal of Product Innovation Management, 36(2): 172-195.

GUMM, H. P. and SOMMER, M. 2009. Einführung in die Informatik. Oldenbourg Verlag.

HAUSCHILDT, J., SALOMO, S., SCHULTZ, C. and KOCK, A. 2016. Innovationsmanagement. Vahlen.

HOMBURG, C. 2017. Marketingmanagement. In: HOMBURG, C. (Ed.). Marketingmanagement: Strategie - Instrumente - Umsetzung - Unternehmensführung. Wiesbaden: Springer Fachmedien Wiesbaden. 
HUANG, S. C.-T. and TSAI, K.-H. 2013. Exploring the drivers of new product success for businesses in Asia: a meta-analysis. Asia Pacific Business Review, 19(3): 303-319.

HULTINK, E. J., GRIFFIN, A., HART, S. and ROBBEN, H. 1997. Industrial new product launch strategies and product development performance. Journal of Product Innovation Management, 14(4): 243-257.

INGENBLEEK, P. T., FRAMBACH, R. T. and VERHALLEN, T. M. 2013. Best practices for new product pricing: Impact on market performance and price level under different conditions. Journal of Product Innovation Management, 30(3): 560-573.

ITTNER, C. D. and LARCKER, D. F. 1997. Product Development Cycle Time and Organizational Performance. Journal of Marketing Research, 34(1), pp. 13-23.

JAWORSKI, B. J. and KOHLI, A. K. 1993. Market Orientation: Antecedents and Consequences. Journal of Marketing, 57(3): 53-70.

JHANG, J. H., GRANT, S. J. and CAMPBELL, M. C. 2012. Get It? Got It. Good! Enhancing New Product Acceptance by Facilitating Resolution of Extreme Incongruity. Journal of Marketing Research, 49(2): 247-259.

JIANG, Z., QU, X. S. and JAIN, D. C. 2018. Optimal market entry timing for successive generations of technological innovations. MIS Quarterly, (forthcoming).

JIN, J. L., SHU, C. and ZHOU, K. Z. 2019. Product newness and product performance in new ventures: contingent roles of market knowledge breadth and tacitness. Industrial Marketing Management, 76 : 231-241.

KÄMPF, T. and BOES, A. 2010. Zeitenwende im Büro: Angestelltenarbeit im Sog der Globalisierung. WSI-Mitteilungen, 63(12): 611-617.

KHAJAVI, S. H., PARTANEN, J., HOLMSTRÖM, J., TUOMI, J. 2015. Risk reduction in new product launch: A hybrid approach combining direct digital and tool-based manufacturing. Computers in Industry, 74: 29-42.

KIM, N., SHIN, S. and MIN, S. 2016. Strategic marketing capability: Mobilizing technological resources for new product advantage. Journal of Business Research, 69(12): 5644-5652.

KOU, T.-C. and LEE, B. C. Y. 2015. The influence of supply chain architecture on new product launch and performance in the high-tech industry. Journal of Business \& Industrial Marketing, 30(5): 677687.

KREUTZER, R. T. 2016. Online-marketing. Wiesbaden: Springer.

KUESTER, S., HOMBURG, C. and HESS, S. C. 2012. Externally directed and internally directed market launch management: the role of organizational factors in influencing new product success. Journal of Product Innovation Management, 29: 38-52.

KUHN, J. 2007. Markteinführung neuer Produkte. $1^{\text {st }}$ Edition. Mannheim: DUV Deutscher UniversitätsVerlag.

KUMAR, A., BEZAWADA, R., RISHIKA, R., JANIKARA, R. and KANNAN, P. K. 2016. From social to sale: The effects of firm-generated content in social media on customer behavior. Journal of Marketing, 80(1): 7-25.

KYRIAKOPOULOS, K., HUGHES, M. and HUGHES, P. 2016. The role of marketing resources in radical innovation activity: antecedents and payoffs. Journal of Product Innovation Management, 33(4): 398-417.

LANGERAK, F. and HULTINK, E. J. 2005. The impact of new product development acceleration approaches on speed and profitability: lessons for pioneers and fast followers. IEEE Transactions on Engineering Management, 52(1): 30-42.

LEDWITH, A. and O'DWYER, M. 2009. Market orientation, NPD performance, and organizational performance in small firms. Journal of Product Innovation Management, 26(6): 652-661.

LEE, Y., LIN, B. W., WONG, Y. Y. and CALANTONE, R. 2011. Understanding and Managing International Product Launch: A Comparison between Developed and Emerging Markets. Journal of Product Innovation Management, 28(s1): 104-120.

LEISSE, O. 2014. Be prepared: 30 Trends für das Business von morgen. Freiburg: Haufe-Lexware.

LOBEL, I., PATEL, J., VULCANO, G. and ZHANG, J. 2015. Optimizing product launches in the presence of strategic consumers. Management Science, 62(6): 1778-1799.

MATIKAINEN, M., RAJALAHTI, T., PELTONIEMI, M., PARVINEN, P. and JUPPO, A. 2015. Determinants of New Product Launch Success in the Pharmaceutical Industry. Journal of Pharmaceutical Innovation, 10(2): 175-189.

MATIKAINEN, M., TERHO, H., PARVINEN, P. and JUPPO, A. 2016. The role and impact of firm's strategic orientations on launch performance: significance of relationship orientation. Journal of Business \& Industrial Marketing, 31(5): 625-639.

MILLSON, M. R. 2012. An examination of the moderation effects of NPD resource allocation and product innovativeness on the NPD stage process proficiency-new product market success relationship. International Journal of Technology Intelligence and Planning, 8(2): 137-160. 
O'DWYER, M. and GILMORE, A. 2019. Competitor orientation in successful SMEs: An exploration of the impact on innovation. Journal of Strategic Marketing, 27(1): 21-37.

O'DWYER, M. and LEDWITH, A. 2008. Product launch, product advantage and market orientation in SMEs. Journal of Small Business and Enterprise Development, 15(1): 96-110.

OECD. 2017. OECD Digital Economy outlook. Paris: OECD Publishing, Paris.

OLEFF, A. and MALESSA, N. 2018. Strategischer Ansatz zur Industrie 4.0-Transformation. ZWF Zeitschrift Für Wirtschaftlichen Fabrikbetrieb, 113(3): 173-177.

OZER, M. and TANG, J. W. 2019. Understanding the trade-off between familiarity and newness in product innovation. Industrial Marketing Management, 77, pp. 116-128.

PANWAR, J. S. and BAPAT, D. 2007. New Product Launch Strategies: Insights from Distributors' Survey. South Asian Journal of Management, 14(2): 82-91.

PLEIL, T., HELFERICH, P. S., GRUPE, M. and WEIGL, S. 2017. Influencer Marketing Studie. [Online]. Available at: http://b2binfluencer.de/influencer-kommunikation-2017/download-whitepaper/ [Accessed: 2019, August 29].

RIJSDIJK, S. A., LANGERAK, F. and HULTINK, E. J. 2011. Understanding a two-sided coin: Antecedents and consequences of a decomposed product advantage. Journal of Product Innovation Management, 28(1): 33-47.

SCHILDMANN, M., BENDIG, D. and BRETTEL, M. 2019. Creating business value through social media: an investigation of the dynamic relationship between social media, brand equity and firm risk. In: Proceedings of the $27^{\text {th }}$ European Conference on Information Systems (ECIS). Stockholm \& Uppsala, Sweden, June 8-14.

SCHOENHERR, T. and SWINK, M. 2015. The Roles of Supply Chain Intelligence and Adaptability in New Product Launch Success. Decision Sciences, 46(5): 901-936.

SEITER, M., BAYRLE, C., BERLIN, S., DAVID, U., RUSCH, M. and TREUSCH, O. 2016. Roadmap Industrie 4.0: Ihr Weg zur erfolgreichen Umsetzung von Industrie 4.0; mit Praxisbeispielen der Unternehmen Carl Zeiss Industrielle Messtechnik GMBH, ESTA Apparatebau GMBH \& Co. KG, Euchner GMBH+ Co. KG, Günther Wirth Hartmetallwerkzeuge Betriebs-GMBH, KSB Aktiengesellschaft und Trumpf GMBH+ Co. KG. Hamburg: Tredition GMBH.

SHEPHERD, C. and AHMED, P. K. 2000. From product innovation to solutions innovation: a new paradigm for competitive advantage. European Journal of Innovation Management, 3(2): 100-106.

SIMAKOVA, E. 2010. RFID 'Theatre of the proof': Product launch and technology demonstration as corporate practices. Social Studies of Science, 40(4): 549-576.

SIMON, H. 2012. Hidden Champions - Aufbruch nach Globalia: Die Erfolgsstrategien unbekannter Weltmarktführer. Frankfurt: Campus Verlag.

SNYDER, H. 2019. Literature review as a research methodology: An overview and guidelines. Journal of Business Research, 104: 333-339.

SONG, L. Z., SONG, M. and DI BENEDETTO, C. A. 2011. Resources, supplier investment, product launch advantages, and first product performance. Journal of Operations Management, 29(1): 86-104.

TALAY, M. B., SEGGIE, S. H. and CAVUSGIL, E. 2009. Exploring Correlates of Product Launch in Collaborative Ventures: An Empirical Investigation of Pharmaceutical Alliances. Journal of Product Innovation Management, 26(4): 360-370.

TALKE, K. and HULTINK, E. 2010. Managing diffusion barriers when launching new products. Journal of Product Innovation Management, 27(4): 537-553.

TALKE, K. and COLARELLI O'CONNOR, G. 2011. Conveying effective message content when launching new industrial products. Journal of Product Innovation Management, 28(6): 943-956.

TALKE, K. and SNELDERS, D. 2013. Information in launch messages: Stimulating the adoption of new high-tech consumer products. Journal of Product Innovation Management, 30(4): 732-749.

TRACEY, J. B. 2014. A review of human resources management research: The past 10 years and implications for moving forward. International Journal of Contemporary Hospitality Management, 26(5): 679-705.

TROMMSDORFF, V. and SCHNEIDER, P. 1990. Grundzüge des betrieblichen Innovationsmanagements. In: Innovationsmanagement in Kleinen und Mittleren Unternehmen. München: Franz Vahlen, pp. 1-25.

TROMMSDORFF, V. and STEINHOFF, F. 2013. Innovationsmarketing. München: Vahlen.

WAHRIG HERKUNFTSWÖRTERBUCH. 2019. Woher kommt digital | Wortherkunft von digital|. [Online]. Available at: https://www.wissen.de/wortherkunft/digital [Accessed: 2019, June 19].

WANG, R. D. and SHAVER, J. M. 2016. The Multifaceted Nature of Competitive Response: Repositioning and New Product Launch as Joint Response to Competition. Strategy Science, 1(3): 148-162.

WILL, D. J., CAMPBELL, K. J. and HOLMES, N. D. 2015. Using digital data collection tools to improve overall cost-efficiency and provide timely analysis for decision making during invasive species eradication campaigns. Wildlife Research, 41(6): 499-509. 
WILLIAMS, C. and VAN TRIEST, S. 2017. Product launch performance in Hi-Tech SMEs: Newness to the firm and the role of management controls. International Journal of Innovation Management, 21(03): 1750022.

WONG, K. S. and TONG, C. 2011. The mediating effects of customer and competitor orientations on new product success. International Journal of Business and Management, 6(8): 34-43.

Contact information

Alexander Salmen: alexander_salmen@yahoo.de 